\title{
Pengaruh Terapi Kelompok Terapeutik dan Pendidikan Kesehatan Terhadap Kecemasan Menghadapi Menarche pada Siswi Di Kelurahan Delima Kecamatan Tampan Pekanbaru
}

\author{
Usraleli*, Magdalena \\ Program Studi Keperawatan Poltekkes Kemenkes Riau \\ *Correspondence email: usraleli@pkr.ac.id
}

\begin{abstract}
Abstrak. Pubertas dipengaruhi oleh keturunan, bangsa, lingkungan, ras atau suku bangsa, faktor iklim, cara hidup, keterpaparan terhadap media masa orang dewasa dan lingkungan. Anak yang telah memasuki masa pubertas akan mengalami menarche. Menarche merupakan suatu tanda awal adanya perubahan pada tubuh seperti pertumbuhan payudara, pertumbuhan rambut daerah pubis dan aksila, serta distribusi lemak pada daerah pinggul. Gejala yang sering menyertai menarche adalah rasa tidak nyaman yang disebabkan karena selama menstruasi volume air di dalam tubuh berkurang. Gejala lain yang dirasakan yaitu sakit kepala, pegal-pegal di kaki dan pinggang untuk beberapa jam, kram perut dan sakit perut. Perubahan fisik di masa pubertas terjadi beriringan dengan pergolakan emosi dan pertumbuhan psikis remaja. Remaja putri yang akan mengalami pubertas memperlihatkan tanda awal dengan adanya menarche menunjukkan perasaan bingung, gelisah, dan perasaan tidak nyaman lainnya seperti ketakutan dan kecemasan. Tujuan penelitian ini adalah untuk mengetahui pengaruh penerapan Terapi Kelompok Terapeutik dan pendidikan kesehatan terhadap tingkat kecemasan menghadapi menarche pada siswi di RW 008 Kelurahan Delima Kecamatan Tampan Pekanbaru. Jenis penelitian Pre Experiment dengan rancangan One Group Pre Test Post Test dilakukan pada 20 responden, dengan menggunakan kuesioner skala HARS. Penelitian ini akan dilaksanakan pada siswi di RW 008 Kelurahan Delima Kecamatan Tampan Pekanbaru dalam kurun waktu observasi selama 4 bulan yang dimulai dari September sampai dengan Devember 2020. Dalam pengambilan sampel, penelitian ini menggunakan teknik Non Probability Sampling dengan jenis Total Sampling dimana metode pemilihan sampel yang dilakukan berdasarkan maksud atau tujuan tertentu yang ditentukan oleh peneliti.
\end{abstract}

Kata kunci: Kecemasan; Menarche; Pendidikan; Kesehatan TKT

\begin{abstract}
Puberty is influenced by heredity, nation, environment, race or ethnicity, climatic factors, way of life, exposure to adult mass media and the environment. Children who have entered puberty will experience menarche. Menarche is an early sign of changes in the body such as breast growth, pubic and axillary hair growth, and fat distribution in the hip area. The symptom that often accompanies menarche is discomfort caused by the reduced volume of water in the body during menstruation. Other symptoms that are felt are headaches, aches in the legs and waist for several hours, stomach cramps and abdominal pain. Physical changes at puberty occur in tandem with emotional upheaval and adolescent psychological growth. Adolescent girls who will experience puberty show early signs of menarche showing feelings of confusion, anxiety, and other uncomfortable feelings such as fear and anxiety. The purpose of this study was to determine the effect of the application of Therapeutic Group Therapy and health education on the level of anxiety facing menarche in female students in RW 008, Delima Village, Tampan District, Pekanbaru. This type of Pre Experiment research with the One Group Pre Test Post Test design was carried out on 20 respondents, using the HARS scale questionnaire. This research will be carried out on students in RW 008, Delima Village, Tampan Pekanbaru District within an observation period of 4 months starting from September to December 2020. In sampling, this study uses the Non Probability Sampling technique with the type of Total Sampling where the sample selection method used is carried out based on certain goals or objectives determined by the researcher.
\end{abstract}

Keywords: Anxiety; Menarche; Education; TKT Health

\section{PENDAHULUAN}

Anak usia sekolah adalah periode yang dimulai dari usia 6-12 tahun, yang artinya sekolah menjadi pengalaman inti anak. Anak-anak dianggap mulai bertanggung jawab atas perilakunya sendiri dalam hubungan dengan orang tua mereka, teman sebaya, dan orang lain. Usia sekolah merupakan masa anak memperoleh dasar-dasar pengetahuan untuk menyesuaian diri pada kehidupan dewasa dan memperoleh keterampilan tertentu (Wong, dkk, 2009). Anak usia sekolah adalah periode yang dimulai saat anak memasuki usia 6 tahun hingga terjadinya pubertas pada usia 12 tahun. Perubahan usia 6 sampai 12 tahun sangat luas dimana ia mengalami perubahan kehidupan dari permainan bebas menjadi kehidupan dengan permainan, pelajaran, dan pekerjaan yang terstruktur. Pertumbuhan dan perkembangan pada anak usia sekolah dipengaruhi oleh lingkungan sekolah dan tempat tinggal (Potter \& Perry, 2009). Lingkungan tempat tinggal dan sekolah merupakan dua tempat yang digunakan untuk melakukan aktivitas belajar, berkreasi, bersosialisasi, dan bergabung kedalam kelompok sebaya, yang merupakan hubungan dekat selain kelompok keluarga pada anak usia sekolah (Efendi \& Makhfudli, 2013).

Anak usia sekolah mengalami pubertas yang menandakan akhir dari masa pertengahan. Masa 
pertengahan antara masa kanak-kanak dan masa dewasa merupakan masa pubertas (Potter \& Perry, 2009). Pubertas adalah masa saat tubuh mulai berkembang dan berubah dari anak-anak menjadi dewasa, dimulai saat anak berusia $\pm 8-13$ tahun yang ditandai dengan perubahan pada tubuh, penampilan dan perasaan (Amalia, 2010). Pubertas dipengaruhi oleh keturunan, bangsa, lingkungan, ras atau suku bangsa, faktor iklim, cara hidup, keterpaparan terhadap media masa orang dewasa dan lingkungan (Kartono, 2006 dalam Nofia, 2016). Anak yang telah memasuki masa pubertas akan mengalami menarche.

Menarche adalah haid/menstruasi pertama yang terjadi pada seorang remaja putri yang sedang menginjak dewasa dan sebagai tanda bahwa wanita sudah mampu hamil (Sarwono, 2005 dalam buku Lusiana, 2015). Haid atau menstruasi adalah luruhnya lapisan dinding bagian dalam rahim yang banyak mengandung pembuluh darah, sehingga haid pada remaja putri ditandai dengan keluarnya darah dari lubang vagina (Pusat Promosi Kesehatan Kementerian Kesehatan RI, 2012). Menarche merupakan suatu tanda awal adanya perubahan pada tubuh seperti pertumbuhan payudara, pertumbuhan rambut daerah pubis dan aksila, serta distribusi lemak pada daerah pinggul. Gejala yang sering menyertai menarche adalah rasa tidak nyaman yang disebabkan karena selama menstruasi volume air di dalam tubuh berkurang. Gejala lain yang dirasakan yaitu sakit kepala, pegal- pegal di kaki dan pinggang untuk beberapa jam, kram perut dan sakit perut. Perubahan fisik di masa pubertas terjadi beriringan dengan pergolakan emosi dan pertumbuhan psikis remaja (Proverawati \& Misaroh, 2009).

Terdapat studi yang telah dilakukan di beberapa negara yang menunjukkan rata-rata umur menarche pada remaja putri di Amerika Serikat adalah 12,8 tahun sementara di China 17 tahun (Rosenthal, 2009). Di Asia seperti Hongkong dan Jepang rata-rata umur menarche remaja putri adalah 12,2 tahun dan 12,38 tahun (Karapanou \& Papadimitriou, 2010). Berdasarkan hasil Riset Kesehatan Dasar tahun 2013, menunjukkan bahwa rata-rata usia menarche di Indonesia adalah 13 tahun, dengan kejadian lebih awal pada usia kurang dari 9 tahun atau lebih lambat sampai usia 17 tahun (Mahmudah, 2014). Berdasarkan Kementerian Kesehatan Republik Indonesia tahun 2010, di Provinsi Riau umur pertama haid pada rentang umur 9-10 tahun sebanyak $1,5 \%$, usia 11-12 tahun sebayak $20,8 \%, 13-$ 14 tahun sebanyak 41,2 \%, 15-16 tahun sebanyak 18,3 $\%, 17-18$ tahun sebanyak 2,4 \% dan di usia 19-20 tahun sebanyak 0,3 \% (Riskesdas, 2010). Remaja putri yang akan mengalami pubertas memperlihatkan tanda awal dengan adanya menarche menunjukkan perasaan bingung, gelisah, dan perasaan tidak nyaman lainnya seperti ketakutan dan kecemasan (Proverawati \& Misaroh, 2009).
Kecemasan adalah gangguan alam perasaan ketakutan atau kekhawatiran yang mendalam dan berkelanjutan, tidak mengalami gangguan dalam menilai realistis, masih baik, kepribadian masih tetap utuh, perilaku dapat terganggu tetapi masih dalam batas-batas normal (Manurung, 2016). Kecemasan adalah gangguan yang berkaitan dengan perasaan khawatir yang berlangsung terus-menerus atas sesuatu yang terjadi (manifestasi) dan kenyataan yang dirasakan disertai dengan rasa ketakutan dan kewaspadaan yang tidak jelas, tidak menyenangkan pada orang yang mengalami gangguan kecemasan (Pieter, Janiwarti dan Saragih, 2011). Kecemasan adalah rasa khawatir, takut yang tidak jelas sebabnya dan merupakan kekuatan yang besar dalam menggerakkan tingkah laku. Baik tingkah laku normal maupun tingkah laku yang menyimpang, yang terganggu, kedua-duanya merupakan pernyataan, penampilan, penjelmaan dari pertahanan terhadap kecemasan (Gunarsa, 2008).

Kecemasan terdiri dari 4 tingkatan yaitu cemas ringan, cemas sedang, cemas berat dan panik. Masingmasing tingkat kecemasan mempengaruhi respon fisiologis, kognitif, perilaku dan emosi (Manurung, 2016). Pengukuran tingkat kecemasan menggunakan skala HRS-A (Hamilton Rating Scale for Anxiety). Penentuan tingkat kecemasan dapat dinilai dari skor yang didapat menggunakan skala HRS-A yaitu jika skor kurang dari 14 menunjukkan tidak ada kecemasan, skor 14-20 menunjukkan kecemasan ringan, skor 21-27 menunjukkan kecemasan sedang, skor 28-41 menujukkan kecemasan berat, dan skor 42-56 menunjukkan kecemasan berat sekali (Hidayat, 2012).

Berdasarkan Penelitian Winarti, et al (2017) tentang "Pengaruh Pendidikan Kesehatan Terhadap Tingkat Kecemasan tentang Menarche Pada Siswi Kelas 5 SDN Sonosewu dan SD Muhammadiyah Ambarbinangun" pada 30 siswi, dan Penelitian Utari (2016) pada 18 siswi dengan judul yang sama. Kedua penelitian tersebut hasilnya sama yaitu terjadi penurunan jumlah responden yang mengalami kecemasan berat setelah dilakukan pendidikan kesehatan. Penelitian terkait lainnya yang dilakukan oleh Pujiati et al (2015) tentang "Pengaruh Pendidikan Kesehatan Tentang Menstruasi Terhadap Tingkat Kecemasan Menghadapi Menarche Pada Siswi Sekolah Dasar" pada 30 siswi didapatkan hasil terjadinya penurunan jumlah responden yang mengalami kecemasan berat setelah dilakukan pendidikan kesehatan.

Berdasarkan studi pendahuluan yang dilakukan peneliti pada tanggal 3 Desember 2019 kepada 10 siswi kelas 5 di SDN 176 Pekanbaru, didapatkan 7 siswi belum menstruasi dan belum memahami tentang menarche sedangkan 3 siswi lainnya sudah mengetahui melalui kakak kelasnya walaupun belum benar-benar paham. Dari 7 siswi yang belum mengalami menstruasi tersebut, 5 diantaranya mengatakan takut dan cemas bila menarche. 3 Desember 2019 kepada 10 siswi kelas 5 di 
SDN 176 Pekanbaru, didapatkan 7 siswi belum menstruasi dan belum memahami tentang menarche sedangkan 3 siswi lainnya sudah mengetahui melalui kakak kelasnya walaupun belum benar-benar paham. Dari 7 siswi yang belum mengalami menstruasi tersebut, 5 diantaranya mengatakan takut dan cemas bila menarche. Wawancara pada tanggal 7 Desember pada 8 orang siswi kelas 6,5 orang diantaranya sudah menstruasi saat kelas 5A 1 orang, saat kelas $5 \mathrm{~B}$ dan $5 \mathrm{C}$ masing-masing 2 orang

Berdasarkan uraian di atas, maka diperlukan suatu pendekatan agar dalam menghadapi menarche tidak mengalami merasa cemas yang berlebihan, pendekatan tersebut dapat dilakukan melalui penerapan Terapi Kelompok Terapeutik (TKT) dan pendidikan kesehatan. Adapun maksud penerapan Terapi Kelompok Terapeutik (TKT) dan pendidikan kesehatan agar siswi memiliki pengetahuan, nilai dan sikap yang positif, merefleksikan cara berpikir dan bertindak (Efendi \& Makhfudli, 2013). Pendidikan kesehatan melalui sekolah paling efektif diantara usaha kesehatan masyarakat yang lain khususnya peran tenaga kesehatan dalam memberikan pendidikan kesehatan karena sekolah merupakan lembaga yang didirikan untuk membina dan meningkatkan sumber daya manusia baik fisik, mental, moral maupun intelektual (Notoatmodjo, 2007 dalam Winarti et al, 2017). Pendidikan kesehatan menstruasi akan membuat remaja putri merasa siap dan tidak takut atau cemas dalam menghadapi menarche, sehingga tidak mengganggu konsentrasi pada siswi untuk belajar (Notoatmodjo, 2003 dalam Utari, 2016).

Berdasarkan latar belakang tersebut dan situasi pandemi covid-19, maka peneliti tertarik untuk melakukan penelitian dengan judul "Pengaruh Terapi Kelompok Terapeutik (TKT) dan pendidikan kesehatan terhadap tingkat kecemasan menghadapi menarche pada siswi di Kelurahan Delima Kecamatan Tampan Pekanbaru".

\section{METODE}

Penelitian ini terdiri dari 4 tahapan penelitian yang terdiri atas tahapan persiapan penelitian, pengumpulan data penelitian, analisis data, dan perbandingan data. Penelitian ini menggunakan metode penelitian Pre Experimental dengan desain penelitian One Group Pretest-Posttest Design, dimana tidak menggunakan kelompok kontrol sebagai pembanding. Pada desain ini terdapat pre-test sebelum diberikan pendidikan kesehatan dan post-test setelah diberikan pendidikan kesehatan terhadap tingkat kecemasan menghadapi menarche pada siswi kelas 5 SD. Penelitian ini menggunakan teknik Purposive Sampling, dimana teknik penentuan sampel tidak memberikan peluang yang sama dari anggota setiap populasi dengan cara pengambilan sampel untuk tujuan tertentu (Setiadi, 2013).

Penelitian ini dilaksanakan pada siswi Sekolah Dasar Negeri 40 Pekanbaru dalam kurun waktu observasi selama 7 bulan yang dimulai dari Desember 2019 sampai dengan Juni 2020. Populasi dalam penelitian ini adalah seluruh siswi kelas 5 SD Negeri 176 Pekanbaru yang belum mengalami menarche dan belum mengetahui tentang menarche yaitu 41 siswi. Sampel dalam penelitian ini adalah siswi kelas 5A, 5B dan 5C di SD Negeri 176 Pekanbaru.

Kriteria pengambilan sampel yang perlu dicantumkan dalam penelitian ini adalah kriteria inklusi dan eksklusi. Adapun kriteria inklusi dari sampel adalah:

a. Siswi yang bersedia menjadi responden.

b. Siswi kelas 5 yang belum mengalami menarche dengan tanda-tanda seks sekunder yaitu payudara tumbuh membesar dan panggul tampak membesar.

c. Siswi yang belum pernah mendapatkan TKT dan pendidikan kesehatan tentang menarche.

d. Siswi yang yang cemas mulai dari tingkat cemas sampai berat

Adapun kriteria eksklusi adalah sebagai berikut:

a. Siswi yang tidak bersedia menjadi responden.

b. Siswi yang tidak hadir saat penelitian.

c. Siswa yang tidak cemas

Pengumpulan data yang dilakukan setelah pengisian kuesioner yaitu peneliti melakukan wawancara kepada responden. Wawancara dilakukan dengan cara mengobservasi tingkah laku (sikap) responden yang disesuaikan dengan gejala kecemasan pada kuesioner. Setelah kuesioner sudah terisi penuh, maka peneliti akan menilai masing-masing kelompok gejala kecemasan dengan memperhatikan tingkat kecemasan yang telah diisi responden. Masing-masing tingkat kecemasan diberi penilaian antara $0-4$. Diberikan nilai 0 apabila responden menchecklist $(\sqrt{ })$ pada kolom tidak ada gejala, nilai 1 apabila responden menchecklist $(\sqrt{ })$ pada kolom gejala ringan, nilai 2 apabila responden menchecklist $(\sqrt{ })$ pada kolom gejala sedang, nilai 3 apabila responden menchecklist $(\sqrt{ })$ pada kolom gejala berat, dan nilai 4 apabila responden menchecklist $(\sqrt{ })$ gejala berat sekali. Setelah isi dari kuesioner dijumlahkan, maka total skor dari kuesioner tersebut dikategorikan tidak ada kecemasan apabila skor kurang dari 14, kategori kecemasan ringan apabila skor 14-20, kategori kecemasan sedang apabila skor 21-27, kategori kecemasan berat apabila skor 28-41, dan kategori kecemasan berat sekali apabila skor 42-56.

Setelah hasil dari kuesioner sudah didapatkan, maka peneliti akan menerapkan Terapi Kelompok Terapeutik (TKT) mulai dari sesi 1 sampai dengan sesi 7 setelah itu peneliti melakukan pendidikan kesehatan tentang menarche kepada responden selama 60 menit dengan metode ceramah, diskusi dan tanya jawab. Setelah pendidikan kesehatan sudah diberikan, peneliti memberikan kuesioner dan melakukan wawancara kembali kepada masing-masing responden. Peneliti akan menilai dan menjumlahkan skor dari kuesioner yang 
telah diisi oleh masing-masing responden untuk mendapatkan hasil dari perlakuan yang sudah diberikan yaitu berupa tingkat kecemasan pada responden tersebut.

\section{HASIL DAN PEMBAHASAN \\ Analisa Univariat}

Karakteristik siswi Sekolah Dasar di RW 008 Kelurahan Delima Kecamatan Tampan Pekanbaru dapat dilihat pada tabel berikut ini:

\section{Umur}

Tabel 1. Distribusi Frekuensi Responden Berdasarkan Umur di RW 008 Kelurahan Delima Kecamatan Tampan Pekanbaru

\begin{tabular}{ccc}
\hline Umur & Frekuensi (Orang) & Presentase (\%) \\
\hline 8 Tahun & 2 & 10 \\
9 Tahun & 4 & 20 \\
10 Tahun & 4 & 20 \\
11 Tahun & $\mathbf{5}$ & $\mathbf{2 5}$ \\
12 Tahun & 2 & 10 \\
13 Tahun & 3 & 15 \\
Jumlah & $\mathbf{2 0}$ & $\mathbf{1 0 0 \%}$ \\
\hline
\end{tabular}

Berdasarkan tabel 1 diketahui bahwa dari 20 responden mayoritas umurnya adalah 11 tahun sebanyak 5 orang $(25 \%)$.

\section{Kelas}

Tabel 2. Distribusi Frekuensi Responden Berdasarkan Kelas di RW 008 Kelurahan Delima Kecamatan Tampan Pekanbaru

\begin{tabular}{ccc}
\hline Kelas & Frekuensi (Orang) & Presentase (\%) \\
\hline II & 2 & 10 \\
IV & $\mathbf{9}$ & $\mathbf{4 5}$ \\
V & 5 & 25 \\
VI & 4 & 20 \\
Jumlah & $\mathbf{2 0}$ & $\mathbf{1 0 0 \%}$ \\
\hline
\end{tabular}

Berdasarkan tabel 2 diketahui bahwa dari 20 responden mayoritas adalah kelas IV sebanyak 9 orang $(45 \%)$.

\section{Tingkat kecemasan sebelum intervensi}

Tabel 3. Distribusi Frekuensi Responden Berdasarkan Tingkat Kecemasan Sebelum Intervensi di RW 008 Kelurahan Delima Kecamatan Tampan Pekanbaru

\begin{tabular}{ccc}
\hline Tingkat Kecemasan & Frekuensi (Orang) & Presentase (\%) \\
\hline Ringan & 4 & 20 \\
Sedang & $\mathbf{1 5}$ & $\mathbf{7 5}$ \\
Berat & 1 & 5 \\
Jumlah & $\mathbf{2 0}$ & $\mathbf{1 0 0 \%}$ \\
\hline
\end{tabular}

Berdasarkan table 3 diketahui bahwa dari 20 responden memiliki tingkat kecemasan sebelum melakukan intervensi mayoritas sedang sebanyak 15 orang $(75 \%)$, ringan sebanyak 4 orang $(20 \%)$ dan berat ada 1 orang $(5 \%)$.

\section{Tingkat kecemasan sesudah intervensi}

Tabel 4. Distribusi Frekuensi Responden Berdasarkan Tingkat Kecemasan Sesudah Intervensi di RW 008 Kelurahan Delima Kecamatan Tampan Pekanbaru

\begin{tabular}{ccc}
\hline Tingkat Kecemasan & Frekuensi (Orang) & Presentase (\%) \\
\hline Ringan & $\mathbf{1 2}$ & $\mathbf{6 0}$ \\
Sedang & 4 & 20 \\
Berat & 1 & 5 \\
Tidak cemas & 3 & 15 \\
Jumlah & $\mathbf{2 0}$ & $\mathbf{1 0 0 \%}$ \\
\hline
\end{tabular}

Berdasarkan tabel 4 diketahui bahwa dari 20 responden memiliki tingkat kecemasan sesudah melakukan intervensi mayoritas ringan sebanyak 12 orang $(75 \%)$.

\section{Analisa Bivariat}

Tabel 5. Hasil Uji Statistik Wilcoxon Pengaruh Terapi Kelompok Terapeutik (TKT) dan Pendidikan Kesehatan Terhadap Tingkat Kecemasan Menghadapi Menarche Pada Siswi Kelas 5 di Sekolah Dasar Negeri Pekanbaru

\begin{tabular}{cccc}
\hline Variabel & N & Z & P Value \\
\hline Pre Tingkat Kecemasan & 20 & -3.500 & 0.000 \\
Post Tingkat Kecemasan & 20 & -3.500 & 0.000 \\
\hline
\end{tabular}

Hasil uji statistik Wilocoxon didapatkan nilai $\mathrm{Z}$ pre dan post tingkat kecemasan sebesar -3.500 dan $\mathrm{p}$ value sebesar 0.000 pada $\alpha 5 \%$ (0.05), yang berarti $\mathrm{p}$ value $<\alpha$. Jadi dapat disimpulkan bahwa ada pengaruh Terapi Kelompok Terapeutik (TKT) dan pendidikan kesehatan terhadap tingkat kecemasan menghadapi menarche pada siswi di RW 008 Kelurahan Delima Kecamatan Tampan Pekanbaru.

\section{Pembahasan}

Berdasarkan hasil penelitian maka peneliti membahas secara sistematik hasil analisa univariat yang terdiri dari karakteristik responden dan analisa bivariat dengan membandingkan teori dan penelitian yang telah dilakukan peneliti mengenai Pengaruh Terapi Kelompok Terapeutik (TKT) dan Pendidikan Kesehatan Terhadap Tingkat Kecemasan Menghadapi Menarche Pada Siswi di RW 008 Kelurahan Delima Kecamatan Tampan Pekanbaru.

\section{Analisa Univariat \\ Umur}

Berdasarkan hasil penelitian yang dilakukan pada 20 responden mayoritas umurnya adalah 11 tahun sebanyak 5 orang $(25 \%)$. Penelitian ini sejalan dengan penelitian Abadi (2015) dengan judul hubungan dukungan keluarga dengan tingkat kecemasan remaja putri dalam menghadapi menarche. Hasil penelitian ini dilakukan pada 275 responden diperoleh hasil sebagian besar responden berusia 11 tahun sebanyak 218 orang $(79,3 \%)$. Hal ini dikarenakan dalam penelitian ini lebih 
menekankan kriteria inklusi yang diambil adalah remaja putri yang berusia 11-12 tahun.

Penelitian ini sejalan dengan penelitian Livana (2019) dengan judul gambaran tingkat ansietas anak usia sekolah saat mengalami menarche. Hasil penelitian ini didapatkan bahwa karakteristik responden berdasarkan usia menarche pada siswi di desa yaitu mayoritas pada usia 11 tahun. Hasil penelitian menunjukkan bahwa usia menarche anak usia sekolah di desa yaitu 10 tahun sebanyak 4 (13,3\%), 11 tahun sebanyak $24(80,0 \%), 12$ tahun sebanyak $2(6,7 \%)$.

Penelitian ini tidak sejalan dengan penelitian yang dilakukan Retnaningsih (2018) dengan judul kesiapan menghadapi menarche dengan tingkat kecemasan pada anak usia sekolah. Hasil penelitian yang dilakukan pada 36 responden diperoleh hasil sebagian besar responden yang berumur 12 tahun sebanyak 12 siswi $(33,3 \%)$. Hal ini menunjukkan bahwa banyak siswi SD yang belum menghadapi menarche.

Usia seorang anak perempuan yang mengalami menarche sangat bervariasi. Anak mendapatkan menarche pada usia yang lebih muda yaitu usia 8 dan 12 tahun. Menarche juga dapat terjadi pada usia 16 tahun (Proverawati \& Maisaroh, 2009). Usia menarche normalnya adalah 12 atau 13 tahun, sebagian perempuan mengalami menstruasi lebih awal (usia 8 tahun) dan lebih lambat (18 tahun) (Sinsin, 2008).

\section{Kelas}

Berdasarkan hasil penelitian dari 20 responden mayoritas adalah kelas IV sebanyak 6 orang (30\%). \%). Penelitian ini sejalan dengan penelitian Retnaningsih (2018) kesiapan menghadapi menarche dengan tingkat kecemasan pada anak usia sekolah. Hasil penelitian yang dilakukan pada 36 responden diperoleh hasil mayoritas responden yang duduk di kelas IV yaitu sebanyak 13 siswi $(36,1 \%)$.

Penelitian ini tidak sejalan dengan penelitian Abadi (2015) dengan judul hubungan dukungan keluarga dengan tingkat kecemasan remaja putri dalam menghadapi menarche. Hasil penelitian didapatkan sebagian besar responden adalah siswi kelas $\mathrm{V}$ sebanyak 206 orang responden $(74,9 \%)$. Hal ini dikarenakan peneliti lebih memilih responden yang berada pada tingkat kelas $\mathrm{V}$ dan IV sebagai perwakilan responden dari tiap-tiap SD yang diteliti.

\section{Tingkat Kecemasan Sebelum Intervensi}

Berdasarkan hasil penelitian yang dilakukan pada 20 responden memiliki tingkat kecemasan sebelum melakukan intervensi adalah sedang sebanyak 15 orang (75\%), ringan sebanyak 4 orang (20\%) dan berat ada 1 orang $(5 \%)$. Peneltian ini tidak sejalan dengan penelitian Pujiati (2015) dengan judul pendidikan kesehatan tentang menstruasi terhadap tingkat kecemasan menghadapi menarche pada siswi sekolah dasar. Hasil penelitian menunjukkan bahwa tingkat kecemasan siswi
SDN 011 Tanjungpinang Barat sebelum diberikan pendidikan kesehatan sebagian besar memiliki tingkat kecemasan berat sebanyak 17 responden $(53,1 \%)$ dan kecemasan berat sekali sebanyak 8 responden $(25 \%)$ hal ini disebabkan karena ketidaktahuan responden mengenai apa itu menstruasi dan cemas menghadapi menarche.

Sesuai dengan teori menurut Gunarsa (2008), kecemasan adalah rasa khawatir, takut yang tidak jelas sebabnya dan merupakan kekuatan yang besar dalam menggerakkan tingkahlaku. Baik tingkahlaku normal maupun tingkahlaku yang menyimpang, kedua-duanya merupakan pernyataan, penampilan, penjelmaan dari pertahanan terhadap kecemasan.

Menarche merupakan menstruasi pertama yang terjadi dalam rentang usia 10-16 tahun atau pada masa awal remaja ditengah masa pubertas sebelum memasuki masa reproduksi (Proverawati \& Maisaroh, 2009). Perubahan penting terjadi, dimana jiwa dan raga anak menjadi matang melalui masa remaja wanita dewasa. Hal ini menandakan bahwa anak sudah memasuki tahap kematangan organ seksual dalam tubuhnya (Pearce, 1999 dalam Proverawati \& Maisaroh, 2009).

Peneliti berpendapat bahwa walaupun menstruasi adalah hal yang wajar dan pasti dialami oleh setiap perempuan, hal ini akan menjadi masalah apabila remaja putri belum pernah mengetahui tentang menstruasi. Kurangnya pengetahuan tentang menstruasi pada remaja putri akan berdampak terhadap kesiapan dan mengalami kecemasan dalam menghadapi menarche.

\section{Tingkat Kecemasan Sesudah Intervensi}

Berdasarkan hasil penelitian yang dilakukan pada 20 responden memiliki tingkat kecemasan sesudah melakukan intervensi adalah ringan sebanyak 12 orang (75\%), sedang sebanyak 4 orang (20\%), berat sebanyak 1 orang $(5 \%)$, dan tidak cemas sebanyak 3 orang $(15 \%)$. $\%)$. Peneltian ini tidak sejalan dengan penelitian Pujiati (2015) dengan judul pendidikan kesehatan tentang menstruasi terhadap tingkat kecemasan menghadapi menarche pada siswi sekolah dasar. Hasil penelitian ini menunjukkan kecemasan berat sebanyak 0 responden (0\%), kecemasan sedang sebanyak 14 responden $(43, \%)$ dan kecemasan ringan sebanyak 3 responden $(9,4 \%)$.

Menurut Pieter (2011) faktor-faktor penyebab kecemasan yaitu berdasarkan teori psikoanalisis ansietas merupakan konflik emosional antara 2 elemen kepribadian, yakni Id, Ego, dan Super-ego. Id mencerminkan dorongan instingtif dan implus-implus primitif. Ego melambangkan mediatir antara $I d$ dan super-ego. Superego mencerminkan hati nurani seseorang yang dikendali oleh norma-norma lingkungan, agama dan budaya. Kaitannya pada ansietas adalah peringatan terhadap pertahanan ego.

Menurut teori Fitriani (2011), konsep dasar pendidikan kesehatan adalah suatu proses belajar yang berarti di dalam pendidikan terjadi proses pertumbuhan, 
perkembangan atau perubahan ke arah yang lebih dewasa, lebih baik, lebih matang pada diri individu, kelompok atau masyarakat. Seseorang dikatakan belajar apabila terjadi perubahan dari tidak tahu menjadi tahu atau dari tidak bisa mengerjakan sesuatu menjadi mampu mengerjakan sesuatu.

Peneliti berpendapat bahwa dengan diberikan pendidikan kesehatan tentang menarche dapat menurunkan angka kecemasan pada remaja putri. Pendidikan kesehatan dapat memberikan informasi pada remaja putri tentang apa itu menarche, usia berapa terjadi menarche, dan faktor penyebab menarche. Dengan adanya pendidikan kesehatan remaja putri menjadi tahu dan dapat mengurangi kecemasan pada saat mengalami menarche.

\section{Analisa Bivariat}

Penelitian ini menggunakan jumlah responden sebanyak 20 responden. Pada hasil uji Wilcoxon didapatkan nilai $p$-value tingkat kecemasan sebelum dan sesudah intervensi sebesar 0.000 pada $\alpha 5 \%(0,05)$ yang berarti bahwa $p$-value < $\alpha$. Jadi dapat disimpulkan bahwa ada pengaruh Terapi Kelompok Terapeutik (TKT) dan pendidilan kesehatan terhadap tingkat kecemasan menghadapi menarche pada siswi kelas 5 di Sekolah Dasar Negeri Pekanbaru.

Penelitian ini sejalan dengan penelitian Pujiati (2015) Dari hasil penelitian pada kelompok eksperimen didapatkan hasil $\mathrm{p}$ value $=0,000$ ( $\mathrm{p}$ value $<\alpha$ ) dapat disimpulkan bahwa H0 ditolak yang artinya ada pengaruh yang bermakan antara pendidikan kesehatan tentang menstruasi terhadap tingkat kecemasan menghadapi menarche pada siswi SDN 011 kelas V dan VI Tanjungpinang Barat.

Hal ini sesuai dengan teori Fitriani (2011), yang menyatakan bahwa pendidikan kesehatan adalah suatu proses belajar yang berarti di dalam pendidikan terjadi proses pertumbuhan, perkembangan atau perubahan ke arah yang lebih dewasa, lebih baik, lebih matang pada diri individu, kelompok atau masyarakat. Seseorang dikatakan belajar apabila terjadi perubahan dari tidak tahu menjadi tahu atau dari tidak bisa mengerjakan sesuatu menjadi mampu mengerjakan sesuatu.

Dalam penelitian Pujiati (2015) mengatakan bahwa pemberian pendidikan kesehatan reproduksi remaja khususnya tentang menstruasi dapat diberikan melalui penyuluhan, sehingga kecemasan remaja putri terhadap menarche dapat berkurang atau bahkan tidak ada. Pendidikan kesehatan tentang menarche bertujuan untuk memberikan informasi kepada siswi tentang pengertian, tanda dan gejala menarche. Dengan pemberian informasi tersebut diharapkan pengetahuan siswi tentang menarche meningkat dan dapat mengurangi kecemasan yang dialami oleh siswi.

Dalam hal ini peneliti dapat menarik kesimpulan bahwa TKT dan pendidikan kesehatan tentang menstruasi sangat bermanfaat dan berguna jika diberikan kepada remaja putri untuk dapat meningkatkan pengetahuan dan menurunkan tingkat kecemasan remaja putri mengenai menstruasi karena dapat mempengaruhi persepsi remaja putri untuk menghadapi menarche.

\section{SIMPULAN}

Dari hasil penelitian yang dilakukan terhadap 30 responden siswi kelas 5 yang akan mengalami menarche di SD Negeri 41 Pekanbaru diberikan intervensi pemberian pendidikan kesehatan maka didapatkan kesimpulan bahwa:

1. Mayoritas tingkat kecemasan responden sebelum diberikan pendidikan kesehatan di SD Negeri 41 Pekanbaru adalah termasuk dalam kategori tingkat kecemasan sedang sebanyak 17 orang $(56,7 \%)$.

2. Mayoritas tingkat kecemasan responden sesudah diberikan pendidikan kesehatan di SD Negeri 41 Pekanbaru adalah termasuk dalam kategori tidak ada kecemasan sebanyak 10 orang $(33,3 \%)$.

3. Adanya pengaruh yang bermakna antara pendidikan kesehatan terhadap tingkat kecemasan menghadapi menarche pada siswi kelas 5 SDN 41 Pekanbaru. Terjadinya penurunan tingkat kecemasan responden sebelum dan sesudah diberikan intervensi pemberian pendidikan kesehatan dengan $p$ value $(0,038)<a$ $(0,05)$ yang artinya Hipotesis alternatif $(\mathrm{Ha})$ diterima dan Hipotesis nol $\left(\mathrm{H}_{0}\right)$ ditolak.

\section{DAFTAR PUSTAKA}

Abadi, Desti Amatika. (2015). Hubungan Dukungan Keluarga dengan Tingkat Kecemasan Remaja Putri dalam Mengahadapi Menarche. Program Studi Ilmu Keperawatan Universitas Riau. Vol 2 No 2, Oktober 2015.

Amalia, T. (2010). The book of puberty: panduan cerdas dan tuntas mengenai pubertas. Jakarta: Serambi Ilmu Semesta

Efendi, F., \& Makhfudli. (2013). Keperawatan kesehatan komunitas: teori dan praktik dalam keperawatan. Jakarta: Salemba Medika

Fitriani, S. (2011). Promosi kesehatan. Yogyakarta: Graha Ilmu

Gunarsa, Singgih D. 2008. Psikologi Anak: Psikologi Perkembangan Anak dan Remaja. Jakarta: PT BPK Gunung Mulia.

Hidayat, A. A. A. (2012). Riset keperawatan dan teknik penulisan ilmiah. Jakarta: Salemba Medika

Karapanou, Olga \& Papadimitriou, Anastasios. (2010). Determinants of menarche. Journal reproductive biology and endocrinology. 21 November 2018. http://www.rbej.com/content/8/1/115

Kementerian Kesehatan RI. (2010). Riset kesehatan dasar tahun 2010: Badan penelitian dan pengembangan kesehatan kementerian kesehatan RI. $24 \quad$ November 2018. http://kesga.kemkes.go.id/images/pedoman/Riskes das \%202010\%20Nasional.pdf 
Usraleli dan Magdalena, Pengaruh Terapi Kelompok Terapeutik dan Pendidikan Kesehatan Terhadap Kecemasan Menghadapi Menarche pada Siswi Di Kelurahan Delima Kecamatan Tampan Pekanbaru

Livana, PH. (2019). Gambaran Tingkat Ansietas Anak Usia Sekolah Saat Mengalami Menarche. Jurnal Kesehatan Vol (12) No (2) Tahun (2019)

Lusiana, N., Andriyani, R., \& Megasari, M. (2015). Buku ajar metodologi penelitian kebidanan. Yogyakarta: Deepublish

Mahmudah, R. T. (2014). Perilaku Remaja Kelas VI SD dalam Menghadapi Menarche di SDN 1 Plalangan Kecamatan Jenangan Kabupaten Ponorogo. Karya Tulis Ilmiah. Fakultas Ilmu Kesehatan Universitas Muhammadiyah Ponorogo

Manurung, N. (2016). Terapi reminiscence. Jakarta Timur: CV. Trans Info Media

Nofia, Vino Rika. (2016). Pengaruh pendidikan kesehatan tentang menarche terhadap kecemasan menghadapi menarche pada siswa kelas 4-6 di SDN 24 ujung gurun kecamatan padang barat. Jurnal Kesehatan Medika Saintika. 17 November 2018.

https://jurnal.syedzasaintika.ac.id/index.php/medi $\mathrm{ka} / \mathrm{article} / \mathrm{view} / 67$

Pieter, H. Z., Janiwarti, B., \& Saragih, M. (2011). Pengantar psikopatologi untuk keperawatan. Jakarta: Kencana

Potter, P. A \& Perry, A. G. (2009). Fundamental keperawatan. Edisi 7. Jakarta: Salemba Medika

Proverawati, A., \& Misaroh, S. (2009). Menarche menstruasi pertama penuh makna. Yogyakarta: Nuha Medika

Pujiati, Wasis. (2015). Pendidikan Kesehatan Tentang Menstruasi Terhadap Tingkat Kecemasan Menghadapi Menarche Pada Siswi Sekolah Dasar. Jurnal Ilmiah Ilmu-Ilmu Kesehatan, Vol 13 No 1, April 2015.

Pusat Promosi Kesehatan Kementerian Kesehatan RI. (2012). Buku petunjuk penggunaan media KIE versi pekerja dan mahasiswa: Aku bangga aku tahu. $21 \quad$ November 2018. http://www.depkes.go.id/resources/download/ promosi-kesehatan/juknis-media-kie-abatpelajar.pdf

Rosenthal, M. S. (2009). Revolusi terapi hormon: pendekatan alami. Yogyakarta: B-First

Setiadi. (2013). Konsep dan praktik penulisan riset keperawatan. Yogyakarta: Graha Ilmu

Sinsin, I. (2008). Seri kesehatan ibu dan anak masa kehamilan dan persalinan. Jakarta: PT. Elex Media Komputindo

Utari, E. P. (2016). Pengaruh Pendidikan Kesehatan Tentang Menstruasi terhadap Tingkat Kecemasan Menghadapi Menarche Pada Siswi Kelas V SD Negeri 16 Pontianak. Naskah Publikasi. Fakultas Kedokteran Universitas Tanjungpura

Wasis Pujiati, Ernawati dan Daratullaila. (2015). Pengaruh pendidikan kesehatan tentang menstruasi terhadap tingkat kecemasan menghadapi menarche pada siswi sekolah dasar.
Jurnal Ilmiah Ilmu-Ilmu Kesehatan. 27 November 2018.

https://jurnalnasional.ump.ac.id/index.php/medisai ns/article/view/ 1821/1498

Winarti, A., Fatimah, S. F., \& Rizky, W. (2017). Pengaruh pendidikan kesehatan terhadap Kecemasan tentang menarche pada siswi kelas V sekolah dasar. Jurnal Keperawatan dan Kebidanan Indonesia. 22 November 2018. https://ejournal.almaata.ac.id./index.php/JNKI

Wong, Donna L., dkk. (2009). Buku Ajar Keperawatan Pediatrik. Edisi 6. Jakarta: EGC 